$\mathrm{Nr} 3(66), 2020$, s. 15-27

\author{
Klaudia KUDŁAWIEC (D) \\ Uniwersytet Jagielloński \\ klaudia.kudlawiec@poczta.onet.pl
}

\title{
INTENSYFIKACJA WSPÓŁPRACY \\ GOSPODARCZEJ W UNII EUROPEJSKIEJ \\ W LATACH 2010-2019 W ŚWIETLE TEORII NOWEJ MIĘDZYRZĄDOWOŚCI
}

ABSTRACT Intensification of Economic Cooperation in the European Union in the Years 2010-2019 in the Light of the Theory of New Intergovernmentality

The subject of the article is the process of intensifying economic integration in the European Union in the years 2010-2019, which is to lead to the creation of a real Economic and Monetary Union. The article is based on the theory of new intergovernmentalism, through which the eurozone system reform has been analyzed. The first part presents the main assumptions of the theory of new intergovernmentalism in relation to two models of European integration: intergovernmental and supranational. The second part was devoted to four projects included in the future Economic and Monetary Union: Financial Union, Economic Union, Fiscal Union and Political Union.

Keywords: reform of the eurozone, new intergovernmentalism, European Commission, new EU method, distribution of power in the European Union

Słowa kluczowe: reforma strefy euro, nowa międzyrządowość, Komisja Europejska, nowa metoda unijna, dystrybucja władzy w Unii Europejskiej 


\section{WSTĘP}

Unia Europejska (UE) od dłuższego czasu zmaga się z wieloma sytuacjami, które zagrażają podstawom jej egzystencji. W 2014 r. rozpoczęły się dwa najpoważniejsze od czasów zakończenia zimnej wojny kryzysy geopolityczne, wywołane wybuchem wojny na Ukrainie oraz utworzeniem Państwa Islamskiego. Te z kolei przyczyniły się do wybuchu w 2015 r. kryzysu migracyjnego, stanowiącego jedno z największych tego typu zjawisk w skali światowej. Społeczeństwo europejskie boryka się równocześnie z tzw. kryzysem tożsamościowym, który odzwierciedla decyzja Wielkiej Brytanii o wyjściu z UE ${ }^{1}$. Niemniej jednak najpoważniejszy kryzys w UE ma charakter systemowy, przejawia się w działaniu tej organizacji oraz istotnie zakłóca dynamikę jej rozwoju². Jego oznaką są istotne różnice koncepcyjne dotyczące przyszłości UE, a w szczególności jej systemu instytucjonalnego. Jest to widoczne zwłaszcza w przypadku struktury unii gospodarczej i walutowej (UGIW). Jej sprawne funkcjonowanie ma priorytetowe znaczenie dla przyszłości UE, ponieważ problemy ekonomiczno-społeczne stanowią jeden z głównych hamulców integracji europejskiej. Istnieje bowiem silna zależność pomiędzy dobrobytem społecznym a legitymizacją jednego z najbardziej interesujących projektów w historii UE, czyli wspólnej waluty europejskiej.

Doskonałymi przykładami potwierdzającymi tę tezę były kryzys zadłużeniowy w niektórych państwach członkowskich strefy euro oraz spadek dynamiki wzrostu gospodarczego w całej UE. Relatywnie niska skuteczność działań podjętych w obliczu światowego kryzysu finansowo-gospodarczego na przełomie lat 2010 i 2011 skłoniła znaczną część elit europejskich do refleksji, iż jedynym remedium na obecne bolączki jest pogłębienie europejskiej integracji polityczno-gospodarczej. Odzwierciedlenie owej opinii stanowi ukierunkowana reforma strefy euro, której głównymi celami są zagwarantowanie wszystkim obywatelom unijnym lepszych i bardziej sprawiedliwych warunków życia oraz przygotowanie UE do sprostania przyszłym wyzwaniom o charakterze globalnym. Ukonstytuowanie rzeczywistej UGIW jest szczególnie ważne, bowiem pierwszorzędnym źródłem problemów ekonomiczno-społecznych zarówno na poziomie unijnym, jak i poszczególnych państw członkowskich jest wadliwa konstrukcja UGIW i strefy euro.

Głównym celem niniejszego artykułu jest odpowiedź na pytanie, jaki model współpracy - ponadnarodowy czy międzyrządowy - sprzyja realizacji celów przewidzianych w reformie strefy euro. W tym kontekście zostaną poddane analizie projekty unii finansowej, unii fiskalnej, unii gospodarczej oraz zrębów unii politycznej, rozpatrywane przez pryzmat teorii nowej międzyrządowości (new intergovernmentalism). W ślad za tym przyjęto dwie hipotezy badawcze. Pierwsza z nich to stwierdzenie, że reforma strefy euro jest esencjonalnym przykładem ukazującym wzrastający udział nowej

\footnotetext{
1 J.J. Węc, Dynamika reformy ustrojowej strefy euro w latach 2012-2016, „Politeja” 2016, Vol. 13, nr 45, s. 200-201.

2 Z. Czachór, Kryzys i zaburzona dynamika Unii Europejskiej, Warszawa 2013, s. 234-241.
} 
metody wspólnotowej w podejmowaniu decyzji w UE. Druga hipoteza zakłada, że proces legislacyjny w tym przedmiocie świadczy o malejącej roli Komisji Europejskiej (KE) i Parlamentu Europejskiego (PE) w konstytuowaniu nowych ram polityki gospodarczej. Badanie zostało przeprowadzone w oparciu o dwie metody jakościowe: analizę instytucjonalno-prawną oraz studium przypadku. Wykorzystanie analitycznego eklektyzmu jako nadrzędnego sposobu badania pozwoliło na triangulację dwóch modeli badawczych dotąd rozpatrywanych odrębnie ${ }^{3}$.

\section{PODSTAWY TEORETYCZNE}

Proces integracji gospodarczej w ramach UE był dotychczas badany przez pryzmat wielu teorii integracji europejskiej: federalizmu, funkcjonalizmu, neofunkcjonalizmu czy klasycznego podejścia międzyrządowego ${ }^{4}$. Większość z nich wywodzi się z paradygmatu liberalnego, akcentującego kluczowe znaczenie postępującej współzależności gospodarczej między państwami dla zapewnienia szeroko pojętego bezpieczeństwa na kontynencie europejskim ${ }^{5}$. Rozwój badań prowadzonych w ramach dyscypliny stosunków międzynarodowych skutkował pojawieniem się nowych modeli integracji europejskiej: liberalnego podejścia międzyrządowego, nowego instytucjonalizmu oraz teorii wielopoziomowego systemu zarządzania, w których podjęto próbę wyjaśnienia coraz bardziej złożonych procesów integracyjnych zachodzących w Europie ${ }^{6}$. Analizując niniejsze ujęcia, można jednak odnieść wrażenie, że prezentowany przez nie model współpracy gospodarczej napotyka na szereg trudności związanych z wyjaśnianiem dynamiki współczesnej integracji gospodarczej.

Punktem wyjścia dla analizy intensyfikacji współpracy gospodarczej jest określenie roli państw członkowskich oraz instytucji ponadnarodowych w konstytuowaniu nowych zasad polityki gospodarczej. Dla rzetelnego zrozumienia postulatów nowej międzyrządowości konieczne jest przedstawienie dwóch modeli teoretycznych integracji gospodarczej, zwanych dla uproszczenia modelem z Maastricht oraz modelem amerykańskim. Pierwszy z nich pogłębia koncept UGIW zawarty w Traktacie z Maastricht, opierający się na ideologii neoliberalizmu, wedle której działalność gospodarcza państw członkowskich powinna być determinowana przez zachowania rynkowe osób fizycznych i prawnych, a nie instytucje polityczne. Ramy teoretyczne ideologii neoliberalizmu odzwierciedlają tym samym istotę podejścia międzyrządowego, które ogranicza się do wzmocnienia dyscypliny fiskalnej w ramach istniejących ram prawnych, bazujących

Szerzej zob. J. Czaputowicz, Czy interdyscyplinarność jest wtaściwym kierunkiem rozwoju stosunków międzynarodowych w Polsce?, [w:] Wielo-i interdyscyplinarność nauki o stosunkach międzynarodowych, red. A. Gałganek, E. Haliżak, M. Pietraś, Warszawa 2012, s. 234.

4 M. Zając-Frąs, Teorie i modele integracji europejskiej, „Zeszyty Naukowe Uniwersytetu Ekonomicznego w Krakowie" 2011, nr 852, s. 3.

5 R. Jackson, G. Sørensen, Wprowadzenie do stosunków międzynarodowych. Teorie i kierunki badawcze, przeł. A. Czwojdrak, Kraków 2010, s. 102-106, Politika.

$6 \quad$ M. Zając-Frąs, Teorie i modele..., s. 5-6, 18. 
na założeniach paktu stabilności i wzrostu ${ }^{7}$. Podstawą modelu z Maastricht jest przekonanie, że ostateczna odpowiedzialność za politykę fiskalną oraz gospodarczą spoczywa na państwach członkowskich ${ }^{8}$.

Podstawą ideologiczną modelu amerykańskiego są natomiast postulaty sformułowane przez Johna Maynarda Keynesa, akcentujące rolę państwa i instytucji politycznych w kształtowaniu życia gospodarczego i łagodzeniu boomów gospodarczych. W tym kontekście pogłębienie integracji gospodarczej miałoby polegać na utworzeniu silnych instytucji ponadnarodowych, czyli przekazaniu przez państwa członkowskie istotnych uprawnień w dziedzinie polityki gospodarczej i podatkowej na szczebel ponadnarodowy. Realizacja modelu amerykańskiego zakłada również pogłębienie współpracy ekonomicznej i politycznej realizowanej w ramach strefy euro?

$\mathrm{Z}$ jednej strony wzmocnienie integracji gospodarczej implikuje konieczność utworzenia wielu nowych instytucji politycznych funkcjonujących na poziomie ponadnarodowym oraz transferu uprawnień państw członkowskich na szczebel ponadnarodowy. Towarzyszący temu procesowi efekt spillover miałby w dłuższej perspektywie doprowadzić do utworzenia ponadnarodowej wspólnoty politycznej, będącej nowym rodzajem państwa narodowego ${ }^{10}$. Z drugiej strony odnosi się wrażenie, że postępującej kooperacji gospodarczej w ramach UE towarzyszy wzrastający udział skonsolidowanej współpracy międzyrządowej w tworzeniu nowych zasad europejskiej polityki gospodarczej ${ }^{11}$. W związku z tym mamy do czynienia z tzw. paradoksem procesu integracji, w ramach którego koordynacja i harmonizacja poszczególnych polityk narodowych odbywają się przy braku transferu władzy na poziom ponadnarodowy. To podejście badawcze w stosunkach międzynarodowych zyskało miano nowej międzyrządowości ${ }^{12}$.

Podstawą niniejszych ram teoretycznych jest naturalny antagonizm występujący pomiędzy państwami członkowskimi a instytucjami ponadnarodowymi, odzwierciedlany przez rywalizację pomiędzy dwoma szczeblami: narodowym i ponadnarodowym ${ }^{13}$. Głównym postulatem jest stwierdzenie, że konsensus wypracowany w ramach organów międzyrządowych - Rady Europejskiej, Rady Unii Europejskiej czy Eurogrupy - jest siłą sprawczą koordynacji polityk na poziomie ponadnarodowym. Przedstawiciele no-

W. Thomas, H. Patrick, E. Howell- Kerry, The European Commission and Fiscal Governance Reform: a Strategic Actor?, „West European Politics” 2017, Vol. 40, nr 6, s. 3-5.

8 T.G. Grosse, Europeizacja jako mechanizm wtadzy: przyktad funkcjonowania strefy euro, [w:] Modernizacja dla spójności spoteczno-ekonomicznej, Rzeszów 2011, s. 19, Nierówności Spoteczne a Wzrost Gospodarczy, nr 19.

9 Tamże, s. 10.

10 E.B. Haas, The Uniting of Europe. Political, Social and Economical Forces, 1950-1957, Stanford 1968, s. $96-98$.

11 T.G. Grosse, Europeizacja jako mechanizm wtadzy..., s. 19.

12 J.C. Bickerton, D. Hodson, U. Puetter, The New Intergovernmentalism: European Integration in the Post-Maastricht Era, „Journal of Common Market Studies” 2015, Vol. 53, nr 4, s. 710-718.

13 J. Ruszkowski, Polska w Unii Europejskiej. W kierunku eurosceptycznej samoizolacji, [w:] Zmierzch demokracji liberalnej?, red. K.A. Wojtaszczyk, P. Stawarz, J. Wiśniewska-Grzelak, Warszawa 2018, s. 509-510. 
wej międzyrządowości kwestionują jednocześnie tradycyjne koncepcje badawcze, zarówno te utożsamiające rozwój integracji z przeniesieniem kompetencji do instytucji ponadnarodowych, jak i te, które redukują ten proces wyłącznie do realizacji swoistych interesów państwowych w ramach instytucji międzyrządowych ${ }^{14}$. Nowe ujęcie koncepcyjne jest więc przeciwstawiane tradycyjnej oraz liberalnej międzyrządowości ${ }^{15}$.

Teoretycy nowej międzyrządowości wskazują jednocześnie na wzrastający udział nowej metody unijnej w podejmowaniu decyzji w UE. Odbywa się to kosztem klasycznej metody wspólnotowej, w ramach której to KE dysponuje wyłącznym prawem do inicjatywy ustawodawczej, a PE wspólnie z Radą Unii Europejskiej stanowią tzw. władzę prawodawczą ${ }^{16}$. Nowa metoda unijna przewiduje możliwość podejmowania wiążących, konsensualnych decyzji przez instytucje międzyrządowe, a także gremia niesformalizowane, które pozostają w luźnym związku z systemem instytucjonalnym UE ${ }^{17}$. Kluczowa rola nowej praktyki decydowania międzyrządowego w UE została po raz pierwszy podkreślona w przemowie Angeli Markel z 2010 r. Kanclerz Niemiec zwróciła uwagę, że w obliczu kryzysu finansowo-gospodarczego i coraz widoczniejszych więzi pomiędzy europejskimi gospodarkami i społeczeństwami należy porzucić dotychczasową rywalizację zwolenników metody międzyrządowej i sympatyków wzmocnienia w UE tzw. architektury ponadnarodowej. Według Merkel traktowanie PE i KE jako jedynych prawdziwych obrońców obywateli unijnych jest pozbawione przesłanek merytorycznych. Nie należy bowiem zapominać, iż państwa członkowskie gromadzące się w Radzie Europejskiej oraz Radzie Unii Europejskiej są konstytutywnymi elementami UE, a nie jej przeciwnikami. W związku z tym nowa metoda unijna ma się opierać na skoordynowanym działaniu wszystkich instytucji unijnych w duchu solidarności przy jednoczesnym dążeniu do osiągnięcia tożsamego celu, którym jest dobrobyt obywateli wszystkich państw członkowskich UE ${ }^{18}$.

Zdaniem przedstawicieli nowej międzyrządowości kryzys gospodarczy i ideowy $\mathrm{w}$ UE doprowadził do osłabienia pozycji instytucji ponadnarodowych $\mathrm{w}$ podejmowaniu decyzji w UE. Jest to szczególnie widocznie w przypadku KE i PE ${ }^{19}$, które nie są już główną siłą napędową integracji. Co więcej można pokusić się o tezę, że instytucje te stały się bardziej stronniczymi organami, które działają w sposób podważający tradycyjną metodę wspólnotową ${ }^{20}$. Nowa międzyrządowość stanowi więc nowatorskie zaplecze teoretyczne, które pomaga w wyjaśnianiu procesu integracji gospodarczej w UE.

14 J.C. Bickerton, D. Hodson, U. Puetter, The New Intergovernmentalism..., s. 704-706.

15 P. Tosiek, „Demokracja międzyrzadowa” - w kierunku rekonstrukcji polskiej koncepcji reformy instytucjonalnej UE, „Rocznik Integracji Europejskiej” R. XI, 2017, s. 374.

16 J.C. Bickerton, D. Hodson, U. Puetter, The New Intergovernmentalism..., s. 707-708.

17 P. Tosiek, Demokracja międzyrządowa..., s. 374.

18 Speech by Federal Chancellor Angela Merkel at the Opening Ceremony of the 61st Academic Year of the College of Europe in Bruges on 2 November 2010, [online] http://www.institutdelors.eu/wp-content/ uploads/2018/01/speech.merkel-english.pdf, 11 XI 2019.

19 T.G. Grosse, Podsumowanie. W kierunku teorii dezintegracji regionalnej, [w:] Polityki europejskie w dobie kryzysu, red. tenże, Warszawa 2016, s. 286-289.

20 J.C. Bickerton, D. Hodson, U. Puetter, The New Intergovernmentalism..., s. 715. 


\section{REFORMA STREFY EURO}

Geneza reformy ustrojowej strefy euro leży u podstaw światowego kryzysu finansowo-gospodarczego z 2008 r., będącego jedną z głównych przyczyn wybuchu kryzysu zadłużeniowego w niektórych państwach należących do strefy euro ${ }^{21}$. W rezultacie na szczeblu unijnym podjęto szereg czynności zmierzających do wzmocnienia zarządzania gospodarczego i budżetowego w UE. W latach 2011-2012 zostały przyjęte nowe regulacje prawne: pakt euro plus, semestr europejski, sześciopak, dwupak, pakt fiskalny oraz traktat ustanawiający Europejski mechanizm stabilności (ESM) ${ }^{22}$. Działania te nie przyniosły jednak wymiernych korzyści, dlatego decydenci europejscy przystąpili do ukierunkowanej reformy ustrojowej strefy euro. Jej podstawami prawnymi są trzeci raport Hermana Van Rompuya ${ }^{23}$, przyjęty w 2012 r. oraz tzw. raport pięciu przewodniczących z 2015 r. ${ }^{24}$ Projektowana architektura UGIW zakłada ustanowienie w jej obrębie trzech nowych struktur, mianowicie unii finansowej, unii gospodarczej i unii fiskalnej, a także zrębów unii politycznejej

\section{PROJEKT UNII FINANSOWEJ}

Pierwszorzędne znaczenie dla przezwyciężenia kryzysu zadłużeniowego w Europie miało powstanie unii finansowej, w skład której wchodzą unia bankowa oraz unia rynków kapitałowych (URK). Według pierwotnego konceptu autorstwa KE unia bankowa miała mieć charakter ponadnarodowy, jednakże w wyniku sprzeciwu państw członkowskich postanowiono, że będzie ona międzyrządową strukturą trzyfilarową opartą na dwóch porządkach prawnych: prawie unijnym oraz umowie międzyrządowej. Analizując proces legislacyjny i rozwiązania prawne przyjęte dla tej struktury, odnosi się wrażenie, że ich głównym pomysłodawcą był rząd niemiecki. Po pierwsze, pod naciskiem Niemiec za fundament Jednolitego Funduszu Restrukturyzacji i Uporządkowanej Likwidacji uznano umowę międzyrządową. Rząd niemiecki oparł swoją argumentację na przekonaniu, że prawodawstwo unijne nie gwarantuje solidnej postawy prawnej

21 K. Kudławiec, Parlament Europejski wobec reformy strefy euro, [w:] Podsumowanie VIII kadencji Parlamentu Europejskiego. Wyzwania integracji europejskiej w latach 2014-2019, red. A. Nitszke, J.J. Węc, Kraków 2019, s. 273.

22 J.J. Węc, Dynamika reformy ustrojowej..., s. 172-173.

23 Towards a Genuine Economic and Monetary Union. Report by President of the European Council Herman van Rompuy, 26 VI 2012, [online] http://ec.europa.eu/economy_finance/crisis/documents/131201_en.pdf, 1 XII 2019.

24 Dokończenie budowy europejskiej Unii Gospodarczej i Walutowej. Sprawozdanie opracowane przez: Jeana-Claudéa Junckera w ścistej wspótpracy z Donaldem Tuskiem, Jeroenem Dijsselbloemem, Mario Draghim i Martinem Schulzem, Komisja Europejska, Bruksela, 22 VI 2015.

25 J.J. Węc, Perspektywy zmian ustrojowych w Unii Europejskiej do 2025 r. Implikacje dla Polski, „Przegląd Zachodni" 2018, nr 1, s. 9. 
dla ustanowienia takiego Funduszu. Po drugie, system głosowania w Jednolitej Radzie, sprawującej nadzór nad Jednolitym Mechanizmem Restrukturyzacji i Uporządkowanej Likwidacji, umożliwia Niemcom oraz Francji formowanie tzw. koalicji blokujących w odniesieniu do pomocy finansowej udzielanej na restrukturyzację banków, która opiewa na kwotę powyżej 5 mld euro bądź jest przyznawana w ramach tzw. restrukturyzacji grupowej. Stanowi to rezultat systemu głosowania w Jednolitej Radzie, w której decyzje są podejmowane zwykłą większością głosów uczestników reprezentujących co najmniej 30\% wysokości składek Funduszu. Państwa te posiadają największy udział w Funduszu, a więc mają możliwość forsowania własnych rozwiązań. Po trzecie, podczas pierwszego etapu reformy strefy euro Niemcy zdecydowały też o harmonizacji działalności krajowych funduszy gwarancyjnych, rezygnując tym samym z ich unifi$\mathrm{kacji}^{26}$. Autorzy raportu pięciu przewodniczących opowiedzieli się jednak za ustanowieniem Europejskiego Systemu Gwarantowania Depozytów z własnym Funduszem Ubezpieczenia Depozytów jako trzeciego filaru unii bankowej, a więc za częściowym uwspólnotowieniem depozytów państw członkowskich ${ }^{27}$. Przyjęcie takich rozwiązań ustrojowych dla unii bankowej jest przejawem malejącej roli klasycznej metody wspólnotowej oraz słabnącej pozycji KE i PE względem rządów państw członkowskich.

Aby ułatwić przedsiębiorstwom i gospodarstwom domowym dostęp do finasowania kapitałowego, URK ma polegać na harmonizacji praktyk w zakresie rachunkowości i rewizji finansowej, uproszczeniu przepisów dotyczących prospektu emisyjnego, utworzeniu rynku sekurytyzacji wysokiej jakości w UE oraz eliminacji tzw. wąskich gardeł utrudniających integrację kapitału. Zwieńczeniem tych działań ma być utworzenie jednolitego europejskiego organu nadzoru rynków kapitałowych, analogicznego do występującego w przypadku unii bankowej ${ }^{28}$. Konstytuowanie URK przebiega niezwykle szybko, nie tylko gwarantując należyty udział KE w owym procesie, lecz także przyczyniając się do unifikacji prawa we wskazanym obszarze ${ }^{29}$.

\section{W KIERUNKU UNII GOSPODARCZEJ}

Druga struktura przyszłej UGIW to unia gospodarcza, której głównym celem jest zagwarantowanie pełnego poziomu zatrudnienia oraz dynamicznego wzrostu gospodarczego we wszystkich państwach członkowskich UE. Potrzeba ściślejszej koordynacji polityki gospodarczej, mającej zwiększyć konkurencyjność i konwergencję państw członkowskich, znalazła po raz pierwszy odzwierciedlenie w podpisanym w $2011 \mathrm{r}$. pakcie euro plus. Umowa ta podkreśla pierwszorzędną rolę szefów państw i rządów w formułowaniu celów gospodarczych i nadzorowaniu ich realizacji przy jednoczesnej

26 Tenże, Proces konstytuowania Unii Bankowej. Geneza, podstawy prawne, cele i zasady dziatania, „Rocznik Integracji Europejskiej” R. VIII, 2014, s. 42-44.

27 Dokończenie budowy europejskiej Unii Gospodarczej i Walutowej..., s. 13.

28 Tamże.

29 K. Kudławiec, Parlament Europejski..., s. 275-276. 
marginalizacji KE, która została uprawiona jedynie do przedstawiania sprawozdań dotyczących wprowadzania reform i wystosowywania zaleceń poszczególnym państwom członkowskim ${ }^{30}$. Mimo ambitnych planów zacieśnienia integracji gospodarczej pakt euro plus nie przyniósł oczekiwanych rezultatów z uwagi na międzyrządowy i niewiążący charakter.

Komisja zwiększyła natomiast zakres swoich kompetencji w ramach zmodyfikowanego semestru europejskiego, w trakcie którego dokonuje przeglądu narodowych projektów budżetowych, prowadzi monitoring państw zagrożonych ryzykiem finansowym oraz wydaje rekomendacje dla poszczególnych krajów dotyczące ich polityk budżetowych, ekonomicznych i społecznych ${ }^{31}$. Formułowaniu niniejszych zaleceń mają służyć wyniki prowadzonej przez KE koordynacji działań tzw. organów ds. konkurencyjności, stanowiących niezależne podmioty, uprawnione m.in. do oceny wysokości wynagrodzeń w państwach członkowskich w zależności od wydajności pracy, a także do monitorowania postępów w zakresie realizacji reform gospodarczych. Mimo rozszerzenia uprawnień KE odnosi się jednak wrażenie, że pełni ona funkcję agencji wykonawczej nieposiadającej zdolności politycznej do forsowania swoich rozwiązańn ${ }^{32}$.

Zdaniem KE w ramach drugiego etapu reformy strefy euro powinno dojść do skodyfikowania procesu konwergencji gospodarczej oraz zwiększenia minimalnych standardów socjalnych, przewidzianych w europejskim filarze praw socjalnych ${ }^{33}$. Wprowadzenie zmian w prawie unijnym pociąga za sobą jednak przymus dalszej harmonizacji przepisów w obszarze rynków pracy, konkurencyjności, otoczenia biznesu, administracji publicznej oraz niektórych aspektów polityki podatkowej ${ }^{34}$. Działaniom tym powinno towarzyszyć przezwyciężenie deficytu demokracji wśród obywateli UE poprzez utworzenie silnych instytucji politycznych funkcjonujących na poziomie ponadnarodowym oraz wzmocnienie uprawnień PE i parlamentów narodowych w tym obszarze.

\section{WSPÓLNE RAMY FISKALNE}

Fundamentalną asymetrią w strukturze instytucjonalnej UGIW było uwspólnotowienie polityki walutowej, znajdującej się pod zwierzchnictwem Europejskiego Banku Centralnego, przy jednoczesnym zdecentralizowaniu polityk fiskalnych, pozostających w gestii rządów poszczególnych państw członkowskich. Z perspektywy czasu jednak wiadomo, że należyte funkcjonowanie unii monetarnej implikuje konieczność

30 E. Kaliszuk, Pakt euro plus, „Polityka gospodarcza Polski w integrującej się Europie” 2010/2011, s. 79-80.

31 P. Świeboda, Ewolucja polskiego stanowiska w sprawie ksztattu instytucjonalnego Unii Europejskiej, „Bezpieczeństwo Narodowe" 2014, nr 4, s. 53.

32 Tamże.

33 Dokument otwierajacy debatę w sprawie pogtębienia Unii Gospodarczej i Walutowej, Komisja Europejska, COM (2017) 291 final, Bruksela, 31 V 2017, s. 23-26.

34 Dokończenie budowy europejskiej Unii Gospodarczej i Walutowej..., s. 10-11. 
przeniesienia szeregu uprawnień fiskalnych na poziom ponadnarodowy, dlatego trzecią strukturą przyszłej UGIW jest unia fiskalna ${ }^{35}$.

Pierwsze kroki na drodze do jej utworzenia ostały podjęte na szczeblu międzyrządowym, podczas nieformalnych gremiów politycznych, w ramach których państwa członkowskie określiły swoje preferencje, wpływając na kierunek polityki gospodarczej realizowanej na etapie wspólnotowym. Taki charakter miały decyzje dotyczące programów ratunkowych oraz fiskalnych mechanizmów stabilizacyjnych strefy euro. Zarówno pakt fiskalny ${ }^{36}$, jak i porozumienie o utworzeniu ESM były umowami międzyrządowymi, akcentującymi kluczową rolę otwartej metody koordynacji jako podstawy strategii ekonomicznej Europy. Co więcej, sekretariat ESM stanowił przez długi czas jeden z głównych ośrodków decyzyjnych w sprawach rekonstrukcji strefy euro i przez większość państw członkowskich był postrzegany jako swoista alternatywa dla $\mathrm{KE}^{37}$.

Postulaty nowej międzyrządowości znalazły odzwierciedlenie również w aktach legislacyjnych wchodzących w skład sześciopaku i dwupaku. Mimo że zostały one przyjęte na podstawie klasycznej metody wspólnotowej, KE została współinicjatorem procedury ustawodawczej razem z grupą zadaniową składającą się z przedstawicieli państw członkowskich pod przewodnictwem Van Rompuya. Niektórzy badacze wskazują nawet, że cały program legislacyjny został opracowany przez RE, a KE pełniła jedynie funkcję sekretariatu wykonawczego. W tym kontekście znaczącą rolę odegrał PE, któremu dzięki prawie dwóm tysiącom poprawek wprowadzonych do wniosków ustawodawczych w ramach trójstronnych negocjacji z Radą Europejską i KE udało się wzmocnić pierwotne postulaty $\mathrm{KE}^{38}$. Jak wskazują Sergio Fabbrini i Uwe Puetter, sześciopak odzwierciedla istotę wzrastającego udziału nowej metody podejmowania decyzji w UE. Za pomocą tego mechanizmu konsensualne porozumienia wypracowane na forum nieformalnych gremiów politycznych, w których uczestniczy zarówno KE, jak i państwa członkowskie, przyjmują formę decyzji legislacyjnych ${ }^{39}$.

W ramach konstytuowanej unii fiskalnej została również utworzona Europejska Rada Budżetowa, będąca nowym organem konsultacyjnym pod nadzorem $\mathrm{KE}^{40}$. Jest ona odpowiedzialna za dostarczanie oceny ex post sposobu wdrażania ram zarządzania budżetowego. Jej ustanowienie świadczy o kluczowym znaczeniu zarządzania technokratycznego w UE, które cechuje się brakiem legitymizacji władzy wśród obywateli UE.

35 Tamże, s. 16-19.

36 Traktat o stabilności, koordynacji i zarządzaniu w unii gospodarczej i walutowej [...], 2 III 2019, [online] https://eur-lex.europa.eu/legal-content/PL/TXT/PDF/?uri=CELEX:42012A0302(01)\&fro$\mathrm{m}=\mathrm{PL}, 10$ XII 2019.

37 P. Świeboda, Ewolucja polskiego stanowiska..., s. 53.

38 M. Sacadura Valle-Flor, The Six-Pack as a Test for the New Intergovernmentalism and Supranationalism Theories, „Revista Brasileira de Política Internacional” 2018, Vol. 61, nr 1, s. 7-8.

39 S. Fabbrini, U. Puetter, Integration without Supranationalisation: Studying the Lead Roles of the European Council and the Council in Post-Lisbon EU Politics, "Journal of European Integration" 2016, no 38, s. 481.

40 Decyzja Komisji (UE) 2015/1937 z dnia 21 października 2015 r. ustanawiająa niezależna doradcza Europejską Radę Budżetowa, Dz.U. UE 2015, L 282/37, s. 37-40. 
Pozostałe propozycje w przedmiocie unii fiskalnej zaprezentowane przez KE zawierały bardziej ambitne plany, dotyczące obszarów poza zasięgiem przyzwolenia politycznego ze strony państw członkowskich. Miały one polegać na częściowym uwspólnotowieniu długu publicznego, ustanowieniu fiskalnego mechanizmu stabilizacyjnego oraz autonomicznego budżetu i organu skarbowego dla strefy euro ${ }^{41}$. Ostatecznie zrezygnowano z większości konceptów, a niektóre uległy znacznej modyfikacji. Najbardziej kontrowersyjna idea utworzenia budżetu dla strefy euro została zastąpiona decyzją o ustanowieniu instrumentu budżetowego na rzecz konwergencji i konkurencyjności (BICC). Co więcej, wypracowanie porozumienia zarówno w sprawie reformy EMS, jak i utworzenia BICC leży w gestii ministrów państw strefy euro, na mocy mandatu udzielonego Eurogrupie w 2018 r., i nie przewiduje uprawnień KE w tym przedmiocie ${ }^{42}$.

Wzmocnienie ponadnarodowej integracji fiskalnej wymusza jednocześnie wprowadzenie zmian w architekturze instytucjonalnej UGIW, czyli stworzenie silnych instytucji politycznych odpowiedzialnych za koordynację tychże polityk. Taką rolę miałyby odgrywać m.in. Europejski Minister Gospodarki i Finansów (EMGiF) oraz Europejski Fundusz Walutowy (EFW). Dotychczas nie udało się osiągnąć porozumienia odnośnie do statusu i uprawnień EMGiF. Zamiast tego w grudniu 2018 r. szefowie państw członkowskich zdecydowali, że EFW pozostanie mechanizmem międzyrządowym, gwarantującym ochronę Jednolitego Funduszu Restrukturyzacji i Uporządkowanej Likwida$\mathrm{cji}^{43}$. W trakcie procedur legislacyjnych pojawiają się także wnioski dotyczące włączenia postanowień paktu fiskalnego do ram prawnych UE oraz ustanowienia jednolitej reprezentacji strefy euro w Międzynarodowym Funduszu Walutowym (MFW) ${ }^{44}$.

\section{WNIOSKI}

Reforma strefy euro jest niewątpliwie procesem absorbującym znaczącą część uwagi politycznej w UE. Nie tylko bowiem wyznacza stopień równowagi między państwami, lecz także determinuje sam charakter procesu integracji. Mimo że podjęto szereg kroków mających na celu budowę rzeczywistej UGIW, większość założeń nie została zrealizowana. Powolne tempo reformy wynika przede wszystkim ze sporów między państwami członkowskimi oraz pomiędzy nimi a KE. Większość dotyczy dystrybucji władzy w ramach przyszłej struktury ustrojowej UGIW. Główna linia podziału przebiega między zwolennikami wzmocnienia infrastruktury ponadnarodowej a tymi, którzy postulują

${ }_{41}$ Dokończenie budowy europejskiej Unii Gospodarczej i Walutowej..., s. 16-17; Komunikat Komisji do Parlamentu Europejskiego, Rady Europejskiej, Rady i Europejskiego Banku Centralnego. Dalsze dziatania na rzecz dokończenia budowy Unii Gospodarczej i Walutowej. Plan dziatania, Bruksela, 6 XII 2017, COM (2017) 821 final, s. 4-9, 11.

42 Szczyt strefy euro. Oświadczenie, Rada Unii Europejskiej, EURO 503/18, Bruksela, 14 XII 2018.

43 Utworzenie Europejskiego Funduszu Walutowego, Parlament Europejski, III 2019, [online] https:// www.europarl.europa.eu/RegData/etudes/ATAG/2019/635535/EPRS_ATA(2019)635535_ PL.pdf, 27 XII 2019.

$44 \quad$ K. Kudławiec, Parlament Europejski..., s. 278-279. 
utrzymanie obecnych ram zarządzania gospodarczego, opartego na modelu współpracy międzyrządowej. Choć wiele wskazywało na to, że doświadczenia państw członkowskich będące skutkiem światowego kryzysu finansowo-gospodarczego doprowadzą Europę do postępów w zakresie wzmocnienia ponadnarodowości, tak się nie stało.

Przeprowadzone badania jednoznacznie potwierdziły przyjęte hipotezy. Pierwszą z nich było stwierdzenie, że reforma strefy euro jest esencjonalnym przykładem ukazującym wzrastający udział nowej metody wspólnotowej w podejmowaniu decyzji w UE. Większość aktów prawnych - pakt euro plus, pakt fiskalny, traktat ustanawiający Europejski mechanizm stabilności oraz umowę ustanawiającą Jednolity Fundusz Restrukturyzacji i Uporządkowanej Likwidacji - przyjęto na podstawie nowej metody unijnej. Co więcej, większość postanowień konstytuujących unię fiskalną oraz unię gospodarczą zapadła na poziomie międzyrządowym, w trakcie nieformalnych gremiów politycznych. W związku z tym KE utraciła monopol na inicjatywę ustawodawczą, będącą kluczowym elementem klasycznej metody wspólnotowej. Druga hipoteza stanowiła, że proces legislacyjny w tym przedmiocie jest odzwierciedleniem malejącej roli $\mathrm{KE}$ i PE w konstytuowaniu nowych ram polityki gospodarczej. Rola KE jako twórcy politycznego procesu integracji została w najważniejszych elementach przejęta przez RE. Idąc krok dalej, można pokusić się o tezę, że KE pełniła wyłącznie funkcje techniczną i wykonawczą w stosunku do rządów państw członkowskich. W związku z tym należy stwierdzić, że to szefowie rządów państw członkowskich, głównie Niemiec i Francji, nadawali ton poszukiwaniu wspólnych rozwiązań, forsując własne propozycje w tym obszarze.

\section{BIBLIOGRAFIA}

Bickerton C.J., Hodson D., Puetter U., The New Intergovernmentalism: European Integration in the Post-Maastricht Era, „Journal of Common Market Studies” 2015, Vol. 53, nr 4, https:// doi.org/10.1111/jcms.12212.

Czachór Z., Kryzys i zaburzona dynamika Unii Europejskiej, Warszawa 2013.

Czaputowicz J., Czy interdyscyplinarność jest wtaściwym kierunkiem rozwoju stosunków międzynarodowych $w$ Polsce?, [w:] Wielo- $i$ interdyscyplinarność nauki o stosunkach międzynarodowych, red. A. Gałganek, E. Haliżak, M. Pietraś, Warszawa 2012.

Decyzja Komisji (UE) 2015/1937 z dnia 21 października 2015 r. ustanawiająca niezależna doradczą Europejskq Radę Budżetowa, Dz.U. UE 2015, L 282/37.

Dokończenie budowy europejskiej Unii Gospodarczej i Walutowej. Sprawozdanie opracowane przez: Jeana-Claude’a Junckera w ścistej wspótpracy z Donaldem Tuskiem, Jeroenem Dijsselbloemem, Mario Draghim i Martinem Schulzem, Komisja Europejska, Bruksela, 22 VI 2015.

Dokument otwierajacy debate w sprawie pogtębienia Unii Gospodarczej i Walutowej, Komisja Europejska, COM (2017) 291 final, Bruksela, 31 V 2017.

Fabbrini S., Puetter U., Integration without Supranationalisation: Studying the Lead Roles of the European Council and the Council in Post-Lisbon EU Politics, ,Journal of European Integration" 2016, Vol. 38, nr 5, https://doi.org/10.1080/07036337.2016.1178254. 
Grosse T.G., Europeizacja jako mechanizm wtadzy: przyktad funkcjonowania strefy euro, [w:] Modernizacja dla spójności spoteczno-ekonomicznej, Rzeszów 2011, Nierówności Spoteczne a Wzrost Gospodarczy, nr 19.

Grosse T.G., Podsumowanie. W kierunku teorii dezintegracji regionalnej, [w:] Polityki europejskie $w$ dobie kryzysu, red. T.G. Grosse, Warszawa 2016.

Haas E.B., The Uniting of Europe. Political, Social and Economical Forces, 1950-1957, Stanford 1968.

Jackson R., Sørensen G., Wprowadzenie do stosunków międzynarodowych. Teorie i kierunki badawcze, przeł. A. Czwojdrak, Kraków 2010, Politika.

Kaliszuk E., Pakt euro plus, „Polityka Gospodarcza Polski w Integrującej się Europie” 2010/2011. Komunikat Komisji do Parlamentu Europejskiego, Rady Europejskiej, Rady i Europejskiego Banku Centralnego. Dalsze dziatania na rzecz dokończenia budowy Unii Gospodarczej i Walutowej. Plan dziatania, Bruksela, 6 XII 2017, COM (2017) 821 final.

Kudławiec K., Parlament Europejski wobec reformy strefy euro, [w:] Podsumowanie VIII kadencji Parlamentu Europejskiego. Wyzwania integracji europejskiej w latach 2014-2019, red. A. Nitszke, J. Węc, Kraków 2019.

Ruszkowski J., Polska w Unii Europejskiej. W kierunku eurosceptycznej samoizolacji, [w:] Zmierzch demokracji liberalnej?, red. K.A. Wojtaszczyk, P. Stawarz, J. Wiśniewska-Grzelak, Warszawa 2018.

Sacadura Valle-Flor M., The Six-Pack as a Test for the New Intergovernmentalism and Supranationalism Theories, „Revista Brasileira de Política Internacional” 2018, Vol. 61, nr 1, https:// doi.org/10.1590/0034-7329201800106.

Speech by Federal Chancellor Angela Merkel at the Opening Ceremony of the 61st Academic Year of the College of Europe in Bruges on 2 November 2010, [online] http://www.institutdelors.eu/ wp-content/uploads/2018/01/speech.merkel-english.pdf.

Szczyt strefy euro. Oświadczenie, Rada Unii Europejskiej, EURO 503/18, Bruksela, 14 IV 2018.

Świeboda P., Ewolucja polskiego stanowiska w sprawie ksztattu instytucjonalnego Unii Europejskiej, „Bezpieczeństwo Narodowe” 2014, nr 4.

Thomas W., Patrick W., Howell-Kerry E., The European Commission and Fiscal Governance Reform: a Strategic Actor?, „West European Politics” 2017, Vol. 40, nr 6, https://doi.org/10.10 80/01402382.2017.1297638.

Tosiek P., „Demokracja międzyrządowa” - w kierunku rekonstrukcji polskiej koncepcji reformy instytucjonalnej UE, „Rocznik Integracji Europejskiej” R. XI, 2017, https://doi. org/10.14746/rie.2017.11.26.

Towards a Genuine Economic and Monetary Union. Report by President of the European Council Herman van Rompuy, 26 VI 2012, [online] https://www.consilium.europa.eu/media/ 33785/131201.pdf.

Traktat o stabilności, koordynacji i zarządzaniu w unii gospodarczej i walutowej [...], 2 III 2019, [online] https://eur-lex.europa.eu/legal-content/PL/TXT/PDF/?uri=CELEX:42012A0 302(01)\&from =PL.

Utworzenie Europejskiego Funduszu Walutowego, Parlament Europejski, III 2019, [online] https://www.europarl.europa.eu/RegData/etudes/ATAG/2019/635535/EPRS_ATA (2019)635535_PL.pdf. 
Węc J.J., Perspektywy zmian ustrojowych w Unii Europejskiej do 2025 r. Implikacje dla Polski, „Przegląd Zachodni” 2018, nr 1.

Węc J.J., Proces konstytuowania Unii Bankowej. Geneza, podstawy prawne, cele i zasady dziatania, „Rocznik Integracji Europejskiej” R. VIII, 2014, https://doi.org/10.14746/rie.2014.8.3.

Węc J.J., Dynamika reformy ustrojowej strefy euro w latach 2012-2016, „Politeja” 2016, Vol. 13, $\mathrm{nr}$ 45, https://doi.org/10.12797/politeja.13.2016.45.09.

Zając-Frąs M., Teorie i modele integracji europejskiej, „Zeszyty Naukowe Uniwersytetu Ekonomicznego w Krakowie” 2011, nr 852.

Mgr Klaudia KUDŁAWIEC - doktorantka w Katedrze Studiów nad Procesami Integracyjnymi w Instytucie Nauk Politycznych i Stosunków Międzynarodowych Uniwersytetu Jagiellońskiego, absolwentka stosunków międzynarodowych na UJ. W pracy naukowej podejmuje tematykę związaną z: systemem instytucjonalnym Unii Europejskiej, integracją gospodarczą, obywatelstwem europejskim, strefą euro, Unią Gospodarczą i Walutową oraz prawem pracy UE. Autorka artykułów, m.in: Parlament Europejski VIII kadencji wobec reformy strefy euro (Podsumowanie VIII kadencji Parlamentu Europejskiego. Wyzwania integracji europejskiej, red. A. Nitszke, J. Węc, Kraków 2019), Nowe zasady delegowania pracowników w Unii Europejskiej („Poszerzamy Horyzonty” 2019, t. 14), Europejska Unia Fiskalna - model ponadnarodowy versus model miedzyrzadowy (w: Instytucjonalizacja procesów integracji europejskiej. Wybrane zagadnienia teoretyczne i funkcjonalne, red. T. Kownacki, A. Wierzchowska, Warszawa 2019). 